\title{
Addressing Childhood Overweight and Obesity: A Focus on India and South Africa
}

\author{
Gwiba Mbobo', Seema Rath², Sean James Bosman³, Sunitha Srinivas ${ }^{1 *}$ \\ ${ }^{1}$ Faculty of Pharmacy, Rhodes University, SOUTH AFRICA. \\ ${ }^{2}$ Hugh Kelly Fellow, Faculty of Pharmacy, Rhodes University, South Africa/Department of Economics, Government College, Khandola- \\ Goa, INDIA. \\ ${ }^{3}$ Department of English, Rhodes University, SOUTH AFRICA.
}

\begin{abstract}
The global prevalence of childhood overweightness and obesity is increasing due to unhealthy diets and a lack of physical activity. A decrease in exclusive breastfeeding of children below 6 months, increased urbanisation, changes in economic status, etc. influence diets and the physical activity of children and lead to increased childhood overweightness and obesity. Childhood overweightness and obesity have negative consequences on a child's physical and mental health. An upsurge of indoor sedentary activities deprives children of physical activity andprevents them from gaining important social and behavioural skills they would learn through social interaction with other children. Obese children are prone to discrimination by society, especially in schools, which can cause lower self-esteem and may further lead to poor mental health and depression. The immense decrease in exclusive breastfeeding of children below 6 months is concurrent with the increasing levels of obesity and overweightness. Several studies have proved that breastfeeding reduces the chances of developing many diseases in the first two years of a child's life as well as later in life, including lower chances of the child becoming obese. India and South Africa, two developing countries, have already introduced measures for the prevention of childhood obesity. India's introduction of community health workers (ASHAs) has already aided in the promotion of breastfeeding. South Africa's sugar tax policy forimplementation in 2017 should have far-reaching effects in lowering childhood overweightness and obesity in the country. Apart from making the already existing interventions more efficient, it is also essential to successfully adopt and implement measures suggested by WHO.
\end{abstract}

Key words: Childhood obesity, Mental health, India, South Africa.

\section{INTRODUCTION}

The global obesity epidemic can have a negative impact on many of the health benefits that have contributed to enhanced life expectancies. ${ }^{1}$ Obesity can affect a child's immediate health, educational attainment and quality of life. Children with obesity are very likely to remain obese as adults and are therefore at risk of chronic illness; and overweight children may become obese children and may grow to be obese adults. ${ }^{2}$ Childhood obesity and overweightnessarelinked to serious health problems that could result in premature death. ${ }^{3}$ Therefore, childhood obesity can lead to an early development of non-communicable diseases (NCDs) such as diabetes and cardiovascular diseases, ${ }^{2}$ as well as to mental health problems ${ }^{4}$ if not treated and prevented early. ${ }^{2}$ Low and middle income countries (LMICs) that lack resources are now facing a double burden of disease, as they are still fighting to end malnutrition ${ }^{5}$ and other highly fatal diseases such as TB and HIV/AIDs, the rising obesity epidemic accompanied by NCDs and mental health problems. This will eventually strain the health services of these nations ${ }^{6}$ if not dealt with immediately. Thus, increases in childhood obesity might emerge as a serious challenge to the attainment of global sustainable development. This paper discusses factors contributing to the rise in childhood overweightness and obesity, considers the consequences of childhood obesity and overweightness, and discusses the
DOI: 10.5530/ijopp.9.2.6

Address for correspondence: Sunitha Srinivas, Faculty of Pharmacy, Rhodes University POBox 94, Grahamstown, SOUTH AFRICA.

E-mail:s.srinivas@ru.ac.za



www.ijopp.org 
current measures taken to reduce the epidemic, as well as considers a way forward to overcome the problem of childhood obesity and overweightness, with particular reference to the two developing countries-India and South Africa.

\section{EXTENT OF CHILDHOOD OVERWEIGHTNESS AND OBESITY}

Globally, over 42 million children under the age of five were obese in 2013, out of which 31 million (73.8\%) were from developing countries. ${ }^{1,2}$ In 2010, it was estimated that, apart from 43 million overweight and obese children worldwide, 92 million more children were in the danger of becoming overweight. ${ }^{3}$ The number of overweight and obese children in absolute terms is higher in low- and middle-income countries (LMICs) than in high-income countries (HICs). In Africa, the number of overweight and obese children has almost doubled between 1990 (5.4 million) and 2014 (10.3 million). ${ }^{1,7}$ In 2014, Asia was home to $48 \%$ of overweight children under 5 years of age, while Africa housed another $25 \% .{ }^{1}$ Overweightness and obesity are preventable, as are the resultant mental health problems and NCDs. ${ }^{2}$

The rate of prevalence of childhood overweightness and obesity in the developing regions is higher in Africa than in Asia. ${ }^{3}$ The Medical Research Council of South Africa estimates that more than $17 \%$ of children between the ages of one and nine years being overweight in urban areas in South Africa. In India, the same trend of high overweight and obese children residing in urban areashas been observed: in Delhi, childhood obesity increased by 8\% between 2002 and $2004 .{ }^{8}$ As per an estimate, $2.2 \%$ of male and $1.7 \%$ of female children were overweight in India in 2014, while the figures for the same stood at $20.6 \%$ and $17.7 \%$ respectively in South Africa. ${ }^{9}$

\section{CAUSES FOR CHILDHOOD OBESITY AND OVERWEIGHTNESS}

\section{Decline in Breastfeeding}

Breastfeeding has many benefits for both mother and child. It decreases the mother's risk of developing type-2 diabetes and ovarian cancer, while benefits for the childare extensive: some of them include a decreased risk of developing sudden infant death syndrome (SIDS), type-2 diabetes and most importantly a reduced possibilityof the child becoming overweight. ${ }^{10} \mathrm{WHO}$ recommends exclusive breastfeeding for up to 6 months, as it not only lowers the risk of the child developing NCDs later on in life but also lowers the possible danger of deathdue to infectious diseases during the first 2 years oflife. ${ }^{11}$
However, despite these benefits, breastfeeding rates in South Africa and Indiaare considerably low. Exclusive breastfeeding up to 6 months between 2008 and 2012 was only $8 \%$ in South Africa ${ }^{12}$ compared to India, which was $46.4 \%$ during the same period. The South African percentages are significantly low when considering that its neighbouring countries like Swaziland and Tanzania had higher rates of $44 \%$ and $50 \%$ respectively. ${ }^{13}$ Whilst India ranked $25^{\text {th }}$ out of 31 countries, its status is far lower than that of neighbouring South East Asian countries like Bangladesh and Afghanistan, which were ranked $12^{\text {th }}$ and $13^{\text {th }}$ respectively by the World Breastfeeding Trends Initiative. ${ }^{14}$

Some of the reasons for low breastfeeding rates are a lack of patient education to address some of the concerns that mothers have such as latching difficulties, painful breasts, and a fear that the supply of milk will not be enough for the child. ${ }^{15}$ Women are also embarrassed of publicly breastfeeding for fear of the negative social views of public breastfeeding that have become more prevalent in recent years due to shifts towards a western cultural paradigmand urbanisation. ${ }^{16}$ Westernised culture has led many to believe that breastfeeding will ruin their breasts and damage their self-image. Single parent households in South Africa have been on the rise, ${ }^{17}$ which in the majority of cases leaves single mothers with all of the responsibilities. This leaves single mothers no choice but to return to work as early as possible after giving birth, as they cannot afford long maternity leave. ${ }^{15}$ Most work environments, especially for women with lower paying jobs,are notflexible enough to allow time for breastfeeding. ${ }^{15}$

One of the main reasons for such a low breastfeeding rate $(8 \%)$ in South Africa is that around 10 years ago the country followed a policy of providing free infant formula to all HIV-positive mothers to prevent HIV transmission from mother to child. This policy discouraged breastfeeding amongst HIV mothers. A new policyinitiated recently encouragesHIV positive mothers to breastfeedusing antiretroviral drugs to reduce the risk of transmission. ${ }^{18,19}$

\section{Economic status}

Generally, children from wealthier families tend to be more obese and overweight than children from poorer backgrounds. An increase in the black middle class in post-apartheid South Africa has led to improved food security ${ }^{20}$ andincreased availability of energy rich processed food. ${ }^{21}$ Even in India, childhood obesity is significantly lower in lower socio-economic sections $(0.42 \%)$ compared to high socio-economic status (5.59\%). This indicates that in developing countries children from wealthier backgrounds are more likely to be overweight 
and obese. ${ }^{22}$ However, children from poorer sections are slowly becoming overweight and obese due to choosing high energy foods like bread and sugary drinks, since they are cheaper than healthier options. ${ }^{23}$

\section{Cultural Beliefs}

Cultural beliefs play a role in childhood obesity. Parents overfeed their child because of the belief that an overweight baby symbolizes healthiness and family wealth. This idea is encouraged in South Africa by the high incidence of HIV/AIDS, with low weight being associated with having HIV/AIDS. ${ }^{21}$

\section{Urbanisation}

Urbanisation has led to a shift from a high fibre, low sugar and low fat diet to one filled with refined food high in carbohydrates and with limitednutritional value for a developing child. ${ }^{24}$ However, in rural areas, families have fruits and vegetables in their gardens, as they depend on agriculture for their livelihood, and the lack of easy accessibility to shops leads to them consuming less processed food. Employed parents in urban areasbuy what is convenient and what requires less time to prepare, which is often unhealthy. It is proven that food not prepared at home is less nutritious. ${ }^{25,26}$ Urbanisation has also lead to decreases in physical activity, resulting in an increased incidence of overweightness and obesity among children.

\section{Lack of Physical Activity}

There has also been a decrease in physical activity due to advancements in technology and mechanics, because over the year's automobiles have replaced walking/ cycling as the main form of transport. Computer games and a rise in the use of cell phones have replaced nonsedentary children's entertainment like soccer, thus causing many children leading physically non-active lifestyles. ${ }^{24}$ UNICEF estimates that there are 250 television sets per thousand inhabitants with children, spending from 1.5 hours to over four hours per day watching television. Watching TV is not only a sedentary activity, ${ }^{25,26}$ it is also away for the powerful media to influence a child's behaviour. Aggressive marketing of the latest gadgets and high sugary food and beverages aimed at children throughTV advertisements further worsens the problems of inactivity and poor diet. ${ }^{27,28}$

People reside in small homes with very little space to garden fresh fruits and vegetables, and lack play areas for children inthe slums of India and communities with shacks in South Africa. ${ }^{29}$ Due to the high crime and child homicide rates in South Africa being double that of the world's average globally, as per WHO, ${ }^{30}$ parents discourage their children from playing outside their house due to the lack of safety. ${ }^{31,32}$ Only parents of a higher socioeconomic class can afford bigger backyards and afford to take their children tosports health clubs to get the necessary physical activity for proper development. ${ }^{24,32}$ Comparable estimates of the prevalence of insufficient physical activity among adolescents (11-17 years) was over 70\% in India in 2007 and is expected to be higher in South Africa. ${ }^{33}$

\section{CONSEQUENCES OF CHILDHOOD OBESITY AND OVERWEIGHTNESS}

Overweightness and obesity in children lead to development of NCDs and decreased mental health wellness.

\section{Quality of Life}

Results of a study showed that Health-Related Quality of Life (QOL) of Severely Obesechildren was lower than the QOL of normal weight children, and the QOL scores of severely obese children was a like to those who had cancer. The paediatric QOL inventory generic core scale considered physical, emotional, social and school functioning in determining the scores. ${ }^{34}$

\section{Physical Problems}

According to $\mathrm{WHO}$, overweight or obese children have an elevated risk of developing NCDs such as diabetes, cardiovascular diseases, and musculoskeletal disorders such as osteoarthritis later in life, which lead to early death and disability. ${ }^{35}$ In India, 1 million people died due to diabetes in 2012, with the onset of diabetes in India occurring 10 years earlier than in most Western countries. The financial costs of diabetes are alarming and were estimated at $\$ 38$ billion in India in $2011 .{ }^{36}$ Even in South Africa, the same problem exists, where in the year $2000,4 \%$ and $10 \%$ of total male and female deaths respectively occurred due to a high Body Mass Index (BMI) for people aged 30 years and above. ${ }^{37}$

\section{Sleep problems}

Obese children were found to be more likely to develop sleep apnoea, which causes daytime drowsiness and insomnia at night. This can further worsen obesity, as it encourages nightsnacking, ${ }^{38}$ as a lack of sleep has been associated with increased appetite ${ }^{39}$ and a lack of energy for physical activity during the day. ${ }^{38}$

\section{Emotional/Psychological problems}

Obesity has often been linked to depression ${ }^{40}$ and other psychological issues such as low self-esteem and poor self-image. ${ }^{41}$ Poor diet due to a shift to high energy dense food ${ }^{2,42}$ and a lack of physical activity due to a sedentary lifestyle, fuelled by advancements in technology, ${ }^{43}$ urbanisation $^{44}$ and other factors contribute to 
some degree to this epidemic. A study found that obese girls of ages 13 to 14 years are four times more likely to experience low self-esteem than those not obese, and to experience higher rates of loneliness and sadness and higher chances of engaging themselves with unhealthy activities like smoking. ${ }^{45}$ Depression might result in over eating and inactivity, in turn leading to further weight gain. ${ }^{46}$ It is awell-known fact that overweightness and depression usually co-exist, even though there is no definitive answer as to which causes which. ${ }^{47}$

Overweight or obese childrenare often excluded from some activities due to pain caused by excess weight on their joints, preventing the child from enjoying and getting involved in sports activities. They are discriminated and stereotyped by classmates, doctors ${ }^{48}$ and "fat shamed" by the media, ${ }^{49}$ making them isolate themselves, which often leads to emotional eating and more weight gain. ${ }^{50}$

A study done on obese children showed that teased children were more likely to be depressed and to engage in unhealthy weight control behaviour ${ }^{51}$ including bulimic episodes. ${ }^{52}$ Another study also found that some teens teased at home and at school had suicidal thoughts, of which 9 percent resulted in attempted suicide. ${ }^{53}$ This is very alarming considering that the suicide rate for children between the ages 10 and 14 years has doubled in South Africa over the last fifteen years. ${ }^{54}$

\section{MEASURES TO REDUCE CHILDHOOD OBESITY AND OVERWEIGHTNESS}

Measures aimed at preventing and reducing childhood and adolescent obesity need to be based on the environmentalcontexts and three criticalstages in the lifecourse: preconception and pregnancy; infancy and early childhood; andolder childhood and adolescence. ${ }^{1}$

In 2008 WHO developed a framework to assist member States in monitoring and evaluating the implementation of DPAS (Global Strategy on Diet, Physical Activity and Health) in efforts to reduce the rising obesity epidemic. It highlighted the importance that everyone become involved, from the private sector to the different sectors in government, including agriculture, education, trade and industry, to get long lasting results.

The Commission on Ending Childhood Obesity has developed a comprehensive, integrated package of recommendations to address childhood obesity, and calls for leadership of governments and for moral responsibility by all stakeholders in reducing the risk of obesity among children. It recommends a multi-stake holder approach, involving governments, non-governmental organisations, private sector, educational institutions and communities by evolving integrated and comprehensive programmes to:

- promote intake of healthy foods and to reduce the intake of unhealthy foods and sugar-sweetened beverages by children and adolescents;

- promote physical activity and reduce sedentary behaviours in children and adolescents;

- provide guidance for preconception,pregnancy and antenatal care, by integrating and strengthening guidance for the prevention of NCDs;

- provide guidance and support for healthy diets, sleep and physical activity in early childhood to ensure children grow appropriately and develop healthy habits;

- promote healthy school environments, health and nutrition literacy,and physical activity among school-age children and adolescents; and

- provide family-based, multicomponent, lifestyle weight management services for children and young people who are obese.

\section{INITIATIVES OF INDIA AND SOUTH AFRICA}

The Government of South Africa has developed a strategy for 2015-2020 to prevent and control obesity, and aims to reduce obesity by $10 \%$ by the year $2020^{55}$.After recognizing the benefits of breastfeeding, South Africa initiated several measures, including the discontinuation of its policy of 2001 in 2011 that distributed free formula for infants at public health facilities, with the intention of preventing transmission of HIV from mother to child, and has started focussing on programmes to boost breastfeeding. ${ }^{56}$ The Government of South Africa will initiate fiscal measures such as a tax on sugar sweetened drinks from 1 April $2017^{57}$ which is found to be one of the most cost-effective measures ${ }^{55}$ to reduce the country's sugar consumption, which leads to obesity and has accounted as one of the factors for the high healthcare costs. ${ }^{58}$ In Mexico, the initiation of sugar tax proved successful, as soda sales decreased by $6 \%$ during its first year of initiation in 2014. ${ }^{59}$

In India, progress with many Reproductive and Child Health Programme indicators after 1998 was slower than before and with some indicators worsening. ${ }^{60}$ India, inits National Action Plan and Monitoring Framework for Prevention of NCDs, has now aimed to halve the rise in obesity prevalence by 2025 . Some of the initiatives suggested include the development and implementation of evidence based public health campaigns for early detection and treatment of obesity, and creating health and nutrition monitoring environments in workplaces and schools, in addition to health facilities. ${ }^{61} \mathrm{By}$ 2015, India had made huge progress. The government 
trained female health workers, called ASHAs, who are located in villages to support and advise expectant and new mothers. One of their main campaigns for promotion of breastfeeding has resulted in increases in exclusively breast-fed children under six months old by $19 \%$ between 2005 and 2006 and 2013 and $2014 .^{62}$ The total number of ASHAs across 32 states in 2015 was $859331 .^{63}$ This indicates that increased child health coverage is feasible, and that it will be easily accessible tolower socio-economic communities in the future. As per the Report of the WHO's NCDs Progress Monitor 2015, India has adopted WHO's set of recommendations on the marketing of foods and non-alcoholic beverages to children. ${ }^{64}$

\section{WAY FORWARD}

Both India and South Africa need a multi-sectoral approach involving all interested parties in order to provide the most effective way of ensuring the reduction in childhood obesity, as this improves a child's physical and mental health.

Role of Government: Government could assess the current and future policies that conflict with health. The Urban Planning and Transport department could allocate a budget for the creation of safe recreation spaces and walking/cycling environments. The gains from sin tax could fund preventative health campaigns, and could provide training opportunities to healthcare professionals, community health care workers, and teachers in schools to improve skills related to diet, physical activity and mental health.

Standard treatment guidelines for diet and physical activity should be developed to ensure that the public is well informed. This will also allow easy initiation of front-pack-traffic-light-labelling, especially for developing countries like India and South Africa, which have low literacy rates. Using colour coded packages to indicate the extent of healthiness of food products will have a huge impact. Standard treatment guidelines also assist in knowing which adverts marketed at children do not meet standard treatment guidelines and need to be regulated.$^{65}$ Health literacy of health information leaflets is quite important, considering the fact that due to a shortage of healthcare professionals(HCPs), HCPs are usually not able to spend enough time on patient counselling, and health information leaflets are thus a good source of information when the patient arrives home. Readability tests are important to ensure that the leaflets are at the literacy level that a majority of patients can understand. ${ }^{66}$

Community: Communities could increase competitive or non-competitive sports activitiesin order to decrease television viewing and other sedentary activities, as this would also develop children's behavioural and social skills. They could create more community gardens to promote fruit and vegetable consumption, as it also promotes physical activity and teaches children selfsufficiency at a young age. Religious and cultural leaders could also participate in promoting healthy body image awareness. ${ }^{65}$

\section{CONCLUSION}

In order to tackle the problem of childhood overweightness and obesity, it is necessary to strengthen and implement pre-existing interventions that could havelong-term positive impact more efficiently.It is also essential to implement the measures suggested by the WHO, such as implementing regulations on food advertisements, creating safe environments for physical activity and facilitating more outdoor sports, games and recreational activities, and to establish community gardens to promote fruit and vegetable consumption. Monitoring systems need to be developed to improve the efficiencyof interventions and for better coordination among all stakeholders to successfullytackle the problem of childhood overweightness and obesity.A healthy childhood would lead to healthy adult life, and lead to sustainable development of countries like India and South Africa.

\section{ABBREVATION USED}

AIDS: Acquired Immune Deficiency Syndrome; ASHA: Accredited Social Health Activist; BMI: Body Mass Index; DPAS: Global Strategy on Diet, Physical Activity and Health, HCP: Health care Professional; HIV: Human Immunodeficiency Virus; HIC: High Income Country; LMIC: Low and Middle Income Country; QOL: Quality of Life; NCD: Non communicable disease; SIDS: Sudden Infant Death Syndrome; TB: Tuberculosis; TV: Television; UNICEF: United Nations Children's Fund; WHO: World Health Organisation.

\section{ACKNOWLEDGEMENT}

The authors gratefully acknowledge Rhodes University for all of its support.

\section{CONFLICT OF INTEREST}

No conflict of interest.

\section{REFERENCES}

1. WHO | Report of the commission on ending childhood obesity 2016 [Internet]. Apps.who.int. 2016 [cited 22 May 2016]. Available from: http://apps.who.int/iris/ bitstream/10665/204176/1/9789241510066_eng.pdf. 
2. WHO | Childhood overweight and obesity [Internet]. World Health Organization. 2016 [cited 22 May 2016]. Available from: http://www.who.int/ dietphysicalactivity/childhood/en/

3. WHO | Global prevalence and trends of overweight and obesity among preschool children [Internet]. Who.int. 2016 [cited 22 May 2016]. Available from: http://www.who.int/nutgrowthdb/publications/overweight_obesity/en/

4. Russell-Mayhew S, McVey G, Bardick A, Ireland A. Mental Health, Wellness, and Childhood Overweight/Obesity. Journal of Obesity. 2012;2012:1-9.

5. WHO | Obesity and overweight [Internet]. World Health Organization. 2016 [cited 22 May 2016]. Available from: http://www.who.int/mediacentre/ factsheets/fs311/en/

6. Prentice A. The emerging epidemic of obesity in developing countries International Journal of Epidemiology. 2005;35(1):93-9.

7. World Obesity Federation | Childhood obesity [Internet]. Worldobesity.org. 2016 [cited 22 May 2016]. Available from: http://www.worldobesity.org/resources/ child-obesity/

8. Bhardwaj S, Misra A, Khurana L, Gulati S, Shah P, Vikram NK. Childhood obesity in Asian Indians: a burgeoning cause of insulin resistance, diabetes and subclinical inflammation.-PubMed-NCBI [Internet]. Ncbi.nlm.nih.gov. 2016 [cited 22 May 2016]. Available from: http://www.ncbi.nlm.nih.gov/pubmed/18296330.

9. FAO | Food and Nutrition in Numbers 2014 [Internet]. $1^{\text {st }}$ ed. Rome: FAO of the United Nations; 2014 [cited 22 May 2016]. Available from: http://www.fao. org/3/a-i4175e.pdf

10. Arenz S, Ruckerl R, Koletzko B, von Kries R. Breast-feeding and childhood obesity - a systematic review. Int J Obes Relat Metab Disord 2004; 28:12471256 .

11. Owen CG, Martin RM, Whincup PH, et al. Effect of infant feeding on the risk of obesity across the life course: a quantitative review of published evidence. Pediatrics. 2005; 115:1367-77.

12. WHO | Exclusive breastfeeding to reduce the risk of childhood overweight and obesity [Internet]. Who.int. 2016 [cited 22 May 2016]. Available from: http:// www.who.int/elena/titles/bbc/breastfeeding_childhood_obesity/en

13. UNICEF | UNICEF statistics [Internet]. Data.unicef.org. 2016 [cited 22 May 2016]. Available from: http://data.unicef.org/resources/breastfeeding-in-the$21^{\text {st }}$-century-epidemiology-mechanisms-and-lifelong-effect.html\#

14. Gupta A, Holla R, Dadhich J. The State of Breastfeeding in 33 Countries in 33 Countries [Internet]. $1^{\text {st }}$ ed. BPNI/IBFANAsia; 2010 [cited 22 May 2016]. Available from: http://www.bfmed.org/Media/Files/Documents/pdf/WBTi\%20 The-state-of-breastfeeding-in-33-countries-2010.pdf

15. Brand E, Kothari C, Stark M. Factors Related to Breastfeeding Discontinuation Between Hospital Discharge and 2 Weeks Postpartum. J Perinat Educ. 2011;20(1):36-44.

16. Loewy P. Nursing bodies: social and cultural constraints on the act of breastfeeding in western society [Internet]. Academia.edu. 2013 [cited 22 May 2016]. Available from: https://www.academia.edu/3476594/NURSING_ BODIES_SOCIAL_AND_CULTURAL_CONSTRAINTS_ON_THE_ACT_OF_ BREASTFEEDING IN WESTERN SOCIETY?auto=download

17. Ndebele T. Only a third of children live with both parents [Internet]. $1^{\text {st }}$ ed. South African Institute of Race Relations; 2013 [cited 22 May 2016]. Available from: http://irr.org.za/reports-and-publications/media-releases/Only\%20 a\%20third\%20of\%20children\%20live \%20with\%20both\%20their\%20parents.. $\mathrm{pdf} /$.

18. UNICEF | In a major policy shift, mothers in South Africa are encouraged to exclusively breastfeed instead of using formula [Internet]. UNICEF. 2016 [cited 22 May 2016]. Available from: http://www.unicef.org/health/southafrica_62139. html

19. Pienaar A. Childhood obesity in South Africa - BMC Series blog [Internet]. BMC Series blog. 2015 [cited 22 May 2016]. Available from: https://blogs. biomedcentral.com/bmcseriesblog/2015/04/07/world-health-day-blog/

20. Dürr B. A toast to South Africa's black middle class | Africa Renewal Online [Internet]. Un.org. 2013 [cited 22 May 2016]. Available from: http://www.un.org/ africarenewal/magazine/december-2013/toast-south-africas-black-middleclass

21. Rossouw HA, Grant CC, Viljoen M. Overweight and obesity in children and adolescents: The South African problem. S Afr J Sci. 2012;108(5/6), Art. \#907, 7 pages. http:// dx.doi.org/10.4102/sajs. v108i5/6.907

22. Manu Raj R. Obesity in children \& adolescents. The Indian Journal of Medical Research [Internet]. 2010 [cited 22 May 2016];132(5):598. Available from: http://www.ncbi.nlm.nih.gov/pmc/articles/PMC3028965/.
23. Child K. Obesity in SA tips the scales [Internet]. Times LIVE. 2013 [cited 22 May 2016]. Available from: http://www.timeslive.co.za/thetimes/2013/02/06/obesityin-sa-tips-the-scales

24. Rhodes University | School of Journalism \& Media Studies. Section 4: What causes obesity [Internet]. Discovery Centre for Health Journalism. 2013 [cited 22 May 2016]. Available from: http://discoverycentre.ru.ac.za/index. php?option=com_content\&view=article\&id=127\&ltemid=196.

25. Devine C.M, Farrell T, Blake C.E, Jastran M, Wethington E, Bisogni C.A (2009). Work Conditions and the Food Choice Coping Strategies of Employed Parents. Journal of Nutrition Education and Behavior. 41(5):365-70.

26. Devine C.M, Jastran M, Jabs J, Wethington E, Farrell T.J, Bisogni C.A. (2006). "A lot of sacrifices:" Work-family spillover and the food choice coping strategies of low-wage employed parents. Social Science \& Medicine. 63:2591-603.

27. Story, M. and French, S. Food Advertising and Marketing Directed at Children and Adolescents in the US. Int J Behav Nutr Phys Act. 2004;1(1):3. Available at: https://ijbnpa.biomedcentral.com/articles/10.1186/1479-5868-1-3 [Accessed 22 May 2016].

28. Healthhabits | Research Proves Junk Food Advertising Causes Childhood Obesity [Internet]. @healthhabits. 2016 [cited 22 May 2016]. Available from: https://healthhabits.ca/2016/01/26/research-proves-junk-food-advertisingcauses-childhood-obesity/

29. Uniteforsight | Urban Versus Rural Health-Global Health University [Internet]. Uniteforsight.org. 2016 [cited 22 May 2016]. Available from: http://www. uniteforsight.org/global-health-university/urban-rural-health

30. Van Zuydamsa L. SA child murder rate double world average | IOL [Internet]. IOL. 2013 [cited 22 May 2016]. Available from: http://www.iol.co.za/news/crimecourts/sa-child-murder-rate-double-world-average-1603154

31. Harvard T.H. Chan | School of public health. Environmental Barriers to Activity [Internet]. Obesity Prevention Source. 2012 [cited 22 May 2016]. Available from: http://www.hsph.harvard.edu/obesity-prevention-source/obesity-causes/ physical-activity-environment/

32. Bristol-Myers Squibb | Low-income Populations and Physical Activity An overview of issues related to active living [Internet]. $1^{\text {st }}$ ed. Active living by design; 2012 [cited 22 May 2016]. Available from: http://www.bms.com/ documents/together_on_diabetes/2012-Summit-Atlanta/Physical-Activity-forLow-Income-Populations-The-Health-Trust.pdf

33. Mendis S. Global Status Report on noncommunicable diseases 2014 [Internet]. $1^{\text {st }}$ ed. World Health Organization; 2014 [cited 22 May 2016]. Available from: http://apps.who.int/iris/bitstream/10665/148114/1/9789241564854_eng.pdf

34. Schwimmer J. Health-Related Quality of Life of Severely Obese Children and Adolescents. JAMA. 2003;289(14):1813.

35. WHO | Why does childhood overweight and obesity matter? [Internet]. Who.int. 2016 [cited 22 May 2016]. Available from: http://www.who.int/ dietphysicalactivity/childhood_consequences/en/

36. Tharkar S, Devarajan A, Kumpatla S, Viswanathan V. "The socioeconomics of diabetes from a developing country: A population based cost of illness study." Diabetes Research and Clinical Practice. 2010;89(3):334-40. Web. March 2013

37. Steyn K. Heart Disease in South Africa [Internet]. $1^{\text {st }}$ ed. The heart and stroke foundation South Africa; 2007 [cited 22 May 2016]. Available from: http://www. heartfoundation.co.za/sites/default/files/Heart\%20Disease $\% 20$ in $\% 20$ SA\%20 MRC\%20Report.pdf

38. Harvard T.H. Chan | School of public health.Sleep [Internet]. Obesity Prevention Source. 2012 [cited 22 May 2016]. Available from: http://www.hsph.harvard. edu/obesity-prevention-source/obesity-causes/sleep-and-obesity/

39. Gloria M. Reeves S. Childhood Obesity and Depression: Connection between these Growing Problems in Growing Children. International Journal of Child Health and Human Development : IJCHD. 2008;1(2):103. [cited 22 May 2016];Available from: http://www.ncbi.nlm.nih.gov/pmc/articles/PMC2568994/

40. Engstrom D. Obesity Action Coalition " Obesity and Depression [Internet]. Obesityaction.org. 2016 [cited 22 May 2016]. Available from: http://www. obesityaction.org/educational-resources/resource-articles-2/obesity-relateddiseases/obesity-and-depression

41. Russell-Mayhew S, McVey G, Bardick A, Ireland A. Mental Health, Wellness, and Childhood Overweight/Obesity. Journal of Obesity. 2012;2012:1-9.

42. Drewnowski A, Specter S.E. Poverty and obesity: the role of energy density and energy costs. The American Journal of Clinical Nutrition. 2004;79(1):6-16. [cited 22 May 2016];Available from: http://ajcn.nutrition.org/content/79/1/6.full

43. Paula E. Obesity in Children and Technology [Internet]. LIVESTRONG COM. 2015 [cited 22 May 2016]. Available from: http://www.livestrong.com/ article/46320-obesity-children-technology/

Indian Journal of Pharmacy Practice, Vol 9, Issue 2, Apr-Jun, 2016 
44. Pirgon Ö Aslan N. The Role of Urbanization in Childhood Obesity. Journal of Clinical Research in Pediatric Endocrinology. 2015;7(3):163-7.

45. $z$

46. Allen A. Overweight Children: Depression Eating [Internet]. WebMD. 2016 [cited 22 May 2016]. Available from: http://www.webmd.com/parenting/raisingfit-kids/mood/depression-eating

47. Willow L. The Obesity-Depression Link [Internet]. Psychology Today. 2003 [cited 22 May 2016]. Available from: https://www.psychologytoday.com/ articles/200305/the-obesity-depression-link

48. Storch E, Milsom V, DeBraganza N, Lewin A, Geffken G, Silverstein J. Peer Victimization, Psychosocial Adjustment, and Physical Activity in Overweight and At-Risk-For-Overweight Youth. Journal of Pediatric Psychology. 2006;32(1):80-9.

49. Heuer C. Obesity Action Coalition " "Fattertainment" - Obesity in the Media [Internet]. Obesityaction.org. 2016 [cited 22 May 2016]. Available from: http:// www.obesityaction.org/educational-resources/resource-articles-2/weight-bias/ fattertainment-obesity-in-the-media

50. Firestone L. What's Behind Emotional Overeating? [Internet]. Psych Alive. 2012 [cited 22 May 2016]. Available from: http://www.psychalive.org/whatsbehind-emotional-overeating/.

51. Madowitz J, Knats S, Crow S and Boutelle K. Teasing, depression and unhealthy weight control behaviour in obese children. - PubMed - NCBI. [Internet] Ncbi.nlm.nih.gov. 2012 [cited 22 May 2016] Available at: http://www. ncbi.nlm.nih.gov/pubmed/22991215

52. Decaluwe' V, Braet C. Prevalence of binge-eating disorder in obese children and adolescents seeking weight-loss treatment.- PubMed - NCBI [Internet]. Ncbi.nlm.nih.gov. 2003 [cited 22 May 2016]. Available from: http://www.ncbi. nlm.nih.gov/pubmed/12629570

53. Paxton $\mathrm{H}$. The effects of Childhood Obesity on Self-Esteem [Internet]. Mds. marshall.edu. 2005 [cited 22 May 2016]. Available from: http://mds.marshall. edu/cgi/viewcontent.cgi?article=1147\&context=etd

54. South African Depression \& Anxiety Group | Teen Suicide [Internet]. Sadag. org. 2016 [cited 22 May 2016]. Available from: http://www.sadag.org/index. php?option=com_content\&view=article\&id=1840\&ltemid=153

55. Department of Health South Africa | Strategy for the Prevention and Control of Obesity in South Africa [Internet]. health-e.org,za; 2015 [cited 22 May 2016]. Available from: https://www.health-e.org.za/wp-content/uploads/2015/12/ National-Strategy-for-prevention-and-Control-of-Obesity-4-August-latest.pdf

56. ljumba P, Doherty T, Jackson D, Tomlinson M, Sanders D, Persson L. Free formula milk in the prevention of mother-to-child transmission programme: voices of a peri-urban community in South Africa on policy change. Health Policy and Planning. 2012;28(7):761-8.

57. Donnelly L. Gordhan announces sugar tax [Internet]. The M\&G Online. 2016 [cited 22 May 2016]. Available from: http://mg.co.za/article/2016-02-24-budgetspeech-2016-gordhan-introduces-sugar-tax

58. Sturm R, An R, Maroba J, Patel D. The effects of obesity, smoking, and excessive alcohol intake on healthcare expenditure in a comprehensive medical scheme. South African Medical Journal [Internet]. 2013;103(11):8404. [cited 22 May 2016] Available from: http://www.samj.org.za/index.php/samj/ article/view/7260/5512

59. Wade L. Mexico's Soda Tax Is Working. The US Should Learn From It [Internet]. WIRED. 2016 [cited 22 May 2016]. Available from: http://www.wired. com/2015/07/mexicos-soda-tax-working-us-learn/.

60. Dabbara D. Reviewing Reproductive and Child Health Programmes in India. [Internet] Academia.edu. 2007 [cited 22 May 2016] Available at: https:// www.academia.edu/1484105/Reviewing_Reproductive_and_Child_Health_ Programmes_in_India?auto=download

61. Government of India | National Action Plan and Monitoring Framework for Prevention and Control of NCDs : Ministry of Health and Family Welfare Government of India [Internet]. Mohfw.nic.in. 2012 [cited 22 May 2016]. Available from: http://www.mohfw.nic.in/showfile.php?lid=2622

62. Bhalla N. Lessons from India on improving women and children's health [Internet]. World Economic Forum. 2015 [cited 22 May 2016]. Available from: https://www.weforum.org/agenda/2015/07/lessons-from-india-on-improvingwomen-and-childrens-health/.

63. Government of India | Update on The ASHA programme [Internet]. Ministry of Health \& Family Welfare Government of India; 2015 [cited 22 May 2016]. Available from: http://ashavani.org/images/docs/Update-on-ASHAProgramme-January-2015.pdf

64. WHO | Noncommunicable diseases progress monitor, 2015. [Internet]. WHO; 2015 [cited 22 May 2016]. Available from: http://apps.who.int/iris/ bitstream/10665/184688/1/9789241509459_eng.pdf

65. WHO | Population-based approaches to childhood obesity prevention [Internet]. WHO; 2012 [cited 22 May 2016]. Available from: http://www. who.int/dietphysicalactivity/childhood/WHO_new_childhoodobesity_ PREVENTION_27nov_HR_PRINT_OK.pdf

66. El-Haddad N, Spooner C, Faruqi N, Denney-Wilson E, Harris M. Readability and content analysis of lifestyle education resources for weight management in Australian general practice. BMC Obesity. 2016;3(1). 